\title{
Factors affecting Non-English Majored Students' Motivation in Learning EFL at Tertiary Level
}

\author{
Nguyen Chau Long ${ }^{1}$, Le Van Tuyen ${ }^{2}$
}

\author{
${ }^{1}$ Da Lat University, Vietnam \\ ${ }^{2}$ Ho Chi Minh City University of Technology (HUTECH), Vietnam
}

\begin{abstract}
Motivation is an important factor that contributes to the success of a foreign language learner. People with high motivation have trend to achieve their needs and wants. Understanding students' motivation in learning English is necessary for EFL teachers. Thus, this study was conducted with the aim of investigating the extent to which non-English majored students at Da Lat University (DLU) are motivated and factors that affect their motivation in learning EFL. A mixed methods design was employed in the study. 150 students majoring in business administration, economics, and tourism, and 5 English teachers participated in the study. Both quantitative and qualitative data were gathered from the questionnaire and semi-structured interviews. The findings showed that the students' integrative motivation, instrumental motivation and social motivation were at a great level. Moreover, the findings indicated eight factors affecting their motivation in learning EFL, including students-related factors, parent-related factors, peer-related factors, teacher personality-related factors, teacher performancerelated factors, teacher feedback-related factors, classroom-related factors, and textbook-related factors. Most of the students agreed that their motivation in learning EFLwas affected by these factors. Based on the findings of the study, recommendations for teachers, students and researchers are included.
\end{abstract}

Keywords-factors, motivation, non-English majored students, affecting, university.

\section{INTRODUCTION}

Motivation is considered as a key feature in the success of language learning and has a great effect on the efficiency and productivity of English language teaching (Gardner \& Lambert, 1972; Gardner \& Brunet, 1977; Dornyei, 2001). It is found through researches (Gao et al., 2004; Kormos\&Dörnyei, 2004; Nguyen Kim Phuoc\& Nguyen Tran Ai Duy, 2018) that learners with high motivation perform better than those with less motivational intensity to learn English as a Foreign Language (EFL). Because of the significance of motivation in L2 learning, many researchers have taken an interest in the issue and it has been widely researched since the 1950s.

Different experimental evidences have shown that some English language learners lose their interest and motivation during the English language learning process because of such factors as teacher related factors, classroom related factors, and student related factors (Dornyei\&Murphey, 2003; Falout\& Maruyama, 2004; Ayako, 2004; Falout\&Falout, 2005; Kikuchi \& Sakai,
2009). Although there have been significant studies exploring factors influencing students' motivation in English learning in the Vietnamese context, those studies focused on English majored students or K-12 students. There is a lack of meaningful studies thatcan provide valuable findings and be utilized to motivate and encourage English learning of non-English majored students.

Regarding the case of DLU, it has designed EFL programs for students with a focus on providing students with substantial English proficiency, ensuring learning outcomes, satisfying employer's demands, and pursuing higher education programs in Vietnam and in developed countries (Phan, H. T., \& Nguyen, T. Q. L, 2017). Particularly, non-English majored students do not have sufficient opportunities and teaching materials to practice English. In addition, the implementation of the program with the employment of innovative techniques to enhance their English proficiency seems not very successful. 
Despite great efforts from the managers and teachers, students' performance in English has not met the requirements and expectations. Poor academic achievements and ineffective communication in English of students reflect their low English competence. Therefore, an investigation into factors influencing motivation of nonEnglish majored students in learning EFL in DLU context is necessary.EFL teachers at DLU need to know the factors affecting motivation so that they can help their students to improve their English proficiency. At that time, they can motivate their students to learn English well. It is expected that the findings of this study will be also significant for other researchers and educators in Vietnam and in other EFL contexts.

\section{AIMS AND OBJECTIVES OF THE STUDY}

The overall aim of this current study is to investigate the factors affecting non-English majored students' motivation in learning EFL at DLU.

The following objectives are derived from the overall aim of the study:

+ To explore the extent to which non-English majored students are motivated in learning English at DLU;

+ To explore the factors that affect non-English majored students' motivation in learning English at DLU.

\section{RESEARCH QUESTIONS}

The study attempted to address the two following research questions

1) To what extent are non-English majored students motivated in learning EFL at DLU?

2) What are the factors that affect non-English majored students' motivation in learning EEL at DLU?

\section{RESEARCH METHODS}

\subsection{Sample and sampling procedures}

Two cohorts of participants participated in the current study. The first cohort included five English teachers who volunteered to participate in the interview. The second cohort consisted of 150 non- Englishmajored students who were studying EFL. They were students majoring in business administration, economics, and tourism. To select this cohort of sample, convenience sampling was employed because the researcher was teaching these classes at the time of conducting the study.

The demographic information of the participants is displayed in the table below.

Table 1: Background information of participants

\begin{tabular}{|c|c|c|c|}
\hline \multicolumn{4}{|l|}{ Students: $N=150$} \\
\hline Category & Demographic information & $\mathbf{n}$ & $\%$ \\
\hline \multirow[t]{3}{*}{ Major } & Business Administration & 50 & $33.33 \%$ \\
\hline & Economics & 50 & $33.33 \%$ \\
\hline & Tourism & 50 & $33.33 \%$ \\
\hline \multirow[t]{2}{*}{ Gender } & Male & 83 & $55.00 \%$ \\
\hline & Female & 67 & $45.00 \%$ \\
\hline \multirow[t]{4}{*}{ Age } & $18-20$ & 20 & $13.00 \%$ \\
\hline & $21-23$ & 39 & $26.00 \%$ \\
\hline & $24-26$ & 63 & $42.00 \%$ \\
\hline & $>27$ & 28 & $19.00 \%$ \\
\hline \multirow[t]{3}{*}{ Years of learning English } & $1-3$ years & 17 & $11.30 \%$ \\
\hline & $4-6$ years & 70 & $46.70 \%$ \\
\hline & Over 7 years & 63 & $42.0 \% 0$ \\
\hline
\end{tabular}




\begin{tabular}{|c|c|c|c|}
\hline \multicolumn{4}{|l|}{ Teachers: $N=5$} \\
\hline Category & Demographic information & $\mathbf{n}$ & $\%$ \\
\hline \multirow[t]{2}{*}{ Gender } & Male & 1 & $20.00 \%$ \\
\hline & Female & 4 & $80.00 \%$ \\
\hline \multirow[t]{3}{*}{ Years of teaching English } & $<5$ years & 0 & $00.00 \%$ \\
\hline & 5-10 years & 1 & $20.00 \%$ \\
\hline & $>10$ years & 4 & $80.00 \%$ \\
\hline
\end{tabular}

\subsection{Research instruments}

Two research instruments were employed in this current study, including the questionnaire and semistructured interview. Regarding the questionnaire,it was designed in the form of Likert scale. It includes 3 parts. Part 1 asks about the participants' demographic information. Part 2 consists of 24 items asking about the students' level of motivation. All were adapted from previous studies, including Integrative motivation (6 items), Instrumental motivation (11 items), and Social motivation (7 items). Part 3 consists of 41 items measuring factors affecting students' motivation in learning English, including student-related factors (4 items), parents-related factors (6 items), peer-related factors (10 items), teacher personality-related factors ( 5 items), teacher performancerelated factors (6 items), teacher feedback-related factors (5 items), classroom-related factors (3 items) and textbook-related factors (2 items).

In terms of reliabilityof 24 items of part 2, Cronbach's Alpha reliability indexeswere calculated to measure the reliability of questionnaire items. The indexes were 0.716 for Integrative motivation ( 6 items); 0.878 for Instrumental motivation (11 items); and0.792 for Social motivation ( 7 items).In terms of reliability of 41 items of part 3 , the indexes of mostfactors are higher than 0.70 except for "teacher personality-related factors": 0.662, and "textbook-related factors": 0.696.Both are lower than 0.70 ,but the indexes are acceptable. Regarding semistructured interviews, questions concerning levels of motivation and factors influencing non-English majored students' motivation in learning English were used for interviewing students and teachers.

\subsection{Data collection procedures}

Data collection was conducted at the end of the academic school year. 150 copies of questionnaire were administered to non-English majored students majoring in business administration, economics, and tourism at DLU. The researcher administered questionnaire copies to the participants within one morning. Before the students completed the questionnaire, the purposes of the ISSN: 2456-7620 surveywere explained to them. Each student spent at least thirty minutes to complete the questionnaire. The questionnaire was adapted from the previous studies and was revised by the two experts and piloted with five students who were not directly involved in the study.

The researcherconducted interviews in the students' tutorial classes. The interviews were conducted in break time. Each student spent five to seven minutes to answer the interview questions. In terms of English teachers, face-to-face in-depth interviews were employed. The place to conductthe interviews with the teachers was in a spare room. To obtain in-depth informationeach interview took 10 to 15 minutes. All interviews were recordedvia an Iphone.

\subsection{Data analysis procedures}

The Statistical Package of Social Sciences (SPSS) was used for the analysis of quantitative data. After the data were collected from the questionnaire, they were sorted out, cleaned, and verified; after that they were entered in the computer for descriptive analysis. For research question 1 , the following criteria in the Likert type scale were used to interpret the data: never true/not at all (N) (1.00-1.80); rarely true/ to some extent (S) (1.812.60); sometimes true/ to a moderate extent (M) (2.61$3.40)$; often true / to a great extent $(\mathrm{G})$ (3.41-4.20); always true/ to a every great extent (VG) (4.21-5.00).

For research question2, the meaning of the mean scores for the students' perceptions of factors influencing their motivation in learning English is interpreted as follows: 1-1.75: Strongly disagree (SD); 1.76-2.50: Disagree (D); 2.51- 3.25: Agree (A); 3.26 - 4.00: Strongly agree (SA).

The responses of interviews were analyzed by using content analysis, which means that three steps, viz. familiarizing and organizing, coding and recoding, and summarizing and interpreting were used. While students were coded as S1, S2, up to S10, English teachers were coded as T1, T2, up to T5 for the analysis. 


\section{RESULTS AND DISCUSSION}

\subsection{The extent to which students are motivated in learning EFL}

Research question 1 attempted to explore the extent to which non-English majored students at DLU are motivated in learning EFL. Data collected from both the questionnaire and teacher and student interviews are presented below:

\section{Integrative motivation}

Table 2. Descriptive Statistics of Integrative motivation

\begin{tabular}{|l|l|l|l|l|l|}
\hline No & \multicolumn{1}{|c|}{ Items } & N & M & St.D & Extent \\
\hline 1 & $\begin{array}{l}\text { English is important because I can learn about the culture and } \\
\text { social life of people from the English speaking countries. }\end{array}$ & 150 & 4.91 & .282 & VG \\
\hline 2 & $\begin{array}{l}\text { Studying English is important because it will enable me to live in } \\
\text { one of the English speaking countries (UK/USA ...) and become } \\
\text { integrated as another member of the community }\end{array}$ & 150 & 3.93 & 472 & $\mathrm{G}$ \\
\hline 3 & $\begin{array}{l}\text { I would like to speak English well because it will allow me to } \\
\text { meet and converse with more and varied people }\end{array}$ & 150 & 4.93 & .428 & VG \\
\hline 4 & $\begin{array}{l}\text { English is important to me because it enables me to join in what is } \\
\text { happening in the world. }\end{array}$ & 150 & 4.82 & .556 & VG \\
\hline 5 & $\begin{array}{l}\text { I am studying English because I would feel ashamed if I could not } \\
\text { speak English when I communicate with my friends from English } \\
\text { speaking countries. }\end{array}$ & 150 & 3.99 & .456 & $\mathrm{G}$ \\
\hline 6 & $\begin{array}{l}\text { I am studying English because I enjoy the feeling of acquiring } \\
\text { knowledge about the English speaking community and their way } \\
\text { of living. }\end{array}$ & 150 & 4.03 & .454 & $\mathrm{G}$ \\
\hline
\end{tabular}

The data displayed in Table 2 show thatall the six items of integrative motivation motivated non-English majored students to a great or a very great extent in learning EFL. In their opinionEnglish is important because they can learn about the culture and social life of people from the English speaking countries (item 1) with $\mathrm{M}=4.91$ and St. $\mathrm{D}=.282$. What is more,studying English is important because it enablesthem to live in one of the English speaking countries and become integrated as another member of the community (item 2) with $\mathrm{M}=3.93$ and St.D $=.472$. Most of them would like to speak English well so that they couldmeet and converse with more and varied people (item 3 ) with $\mathrm{M}=4.93 \& \mathrm{St} . \mathrm{D}=.428$. Nearly all of them think that English is important because it enables them to join in what is happening in the world (item 4) with $\mathrm{M}=4.82 \& \mathrm{St} . \mathrm{D}=.556$. Particularly, the studentswould feel ashamed if they could not speak English when they communicate with friends from English speaking countries (item 5) with $\mathrm{M}=3.99$ and St.D $=.456$, and they enjoy feeling of acquiring knowledge about the English speaking community and their way of living (item 6) with $\mathrm{M}=4.03$ and St.D=.454.
Regarding the data collected from the interviews with ten students and five English teachers, it was found that many students gave the reasons to learn English. For example, some studentsreported:

"I learn English because I want to open my eyes and know a lot about the outside world,make friends with many foreigners, and hopefully after graduation I can find good jobs, high promotion opportunities" (S4). Or S8 expressed that "I want to have the opportunity to go abroad to live and work because the outside world is always new and interesting. I want to explore many places in the world, and understand many countries and make friends with many people".

Regarding the interview with the teachers, they also showed their opinions. Some of them said:

"I find many students very motivated to learn English because they recognize the 
important role that English plays in their careers and their lives. However, there are also students who are not interested in learning English because they may not have an English background, so they feel bored when they focus on learning."(T1)

"I find that although my students' English language proficiency is low, many of them really like learning English. They come to class regularly and often do assignments carefully. IN class they participated in activities actively" (T3)

\section{Instrumental motivation}

Table 3. Descriptive Statistics of Instrumental motivation

\begin{tabular}{|c|c|c|c|c|c|}
\hline No & Items & $\mathrm{N}$ & Mean & St.D & Extent \\
\hline 7 & $\begin{array}{l}\text { Studying English is important because I will need it for my } \\
\text { future studies. }\end{array}$ & 150 & 4.74 & .937 & VG \\
\hline 8 & $\begin{array}{l}\text { Studying English is important because it will be useful in } \\
\text { getting a good and well-paid job. }\end{array}$ & 150 & 4.86 & .526 & VG \\
\hline 9 & $\begin{array}{l}\text { Studying English is important because it enables me to } \\
\text { work abroad. }\end{array}$ & 150 & 3.35 & .890 & M \\
\hline 10 & $\begin{array}{l}\text { I would like to read the literature and watch films in the } \\
\text { original language. }\end{array}$ & 150 & 3.77 & .532 & $\mathrm{G}$ \\
\hline 11 & $\begin{array}{l}\text { Studying English is important because it enables me to } \\
\text { communicate and deal with problems when travelling } \\
\text { abroad. }\end{array}$ & 150 & 3.76 & .765 & $\mathrm{G}$ \\
\hline 12 & $\begin{array}{l}\text { I am studying English in order to get more academic } \\
\text { success later on. }\end{array}$ & 150 & 4.71 & .744 & VG \\
\hline 13 & $\begin{array}{l}\text { I am studying English for the satisfaction I feel when I am } \\
\text { in the process of accomplishing difficult exercises in } \\
\text { English. }\end{array}$ & 150 & 3.46 & .816 & $\mathrm{G}$ \\
\hline 14 & $\begin{array}{l}\text { I am studying English Because I think it is good for my } \\
\text { personal development. }\end{array}$ & 150 & 3.80 & .602 & $\mathrm{G}$ \\
\hline 15 & $\begin{array}{l}\text { I am studying English for the satisfied feeling I get in } \\
\text { learning new things. }\end{array}$ & 150 & 3.75 & .623 & $\mathrm{G}$ \\
\hline 16 & $\begin{array}{l}\text { I am studying English for the enjoyment I experience when } \\
\text { I grasp a difficult construct in English. }\end{array}$ & 150 & 4.08 & .561 & $\mathrm{G}$ \\
\hline 17 & $\begin{array}{l}\text { I am studying English because I have to meet the } \\
\text { requirements/expectations of my university /lecturers/ } \\
\text { parents. }\end{array}$ & 150 & 3.68 & .557 & G \\
\hline
\end{tabular}

Table 3 describes descriptive statistics of instrumental motivation. Itcan be seen that all the items of instrumental motivation motivated the students to a great or a very great extent. Among 10 items, 3 items obtained the students' agreement to a very great extent. Those are item $8,7 \& 12$. Accordingly, studying English was important because it would be useful for them to get a good and well-paid job (item 8) with $\mathrm{M}=4.86 \& \mathrm{St} . \mathrm{D}=.526$, to need it for their future studies (item 7 ) with $\mathrm{M}=4.74 \& \mathrm{St} . \mathrm{D}=.937$, and to get more academic success later on (item 12) $\mathrm{M}=4.71$ \&St.D=.744.

Regarding 7 other items, 6 of them motivated the students to a great extent. Accordingly, the students learn English for enjoyment (item 16) with $\mathrm{M}=4.08$ $\& S t . D=.561$, for their personal development (item 14) with $\mathrm{M}=3.80$ \&St. $\mathrm{D}=.602$, for reading the literature watch films in the original language (item 10)with $\mathrm{M}=3.77$ $\& S t . D=.532$. In addition, they also learn English for 
communication when traveling abroad (item 11) with $\mathrm{M}=3.76$ \&St. $\mathrm{D}=.765$, for satisfaction when learning new things (item 15) with $\mathrm{M}=3.75 \&$ St. $\mathrm{D}=.623$. In addition, the students said that they learn English for meeting the requirements/expectations of university /lecturers/ parents (item 17) with $\mathrm{M}=3.68 \& \mathrm{St} . \mathrm{D}=.557$, and for the satisfaction when accomplishing difficult exercises in English (item 13) with $\mathrm{M}=3.46 \quad \& S t . D=.816$. More interestingly, only one item motivated the students to a moderate extent. It is "studying English is important because it enables them to work abroad" with $\mathrm{M}=3.35$ $\& S t . D=.890$. Obviously, working abroad is not the motive of many students. It can be concluded that instrumental motivationmotivated the non-English students at DLU. All of the students had similar purposes of learning English.

Responding to the interview question concerning the instrumental motivations, students expressed their opinions that are similar to the data collected from the questionnaire. For example, some students stated:

"My purpose in learning English is to get a good and well-paid job, I can meet and chat with many foreign friends, participate in many outside activities" (S3). Or "My purpose of studying

Table 4 : Descriptive Statistics of Social motivation

\begin{tabular}{|l|l|l|l|l|l|}
\hline No & \multicolumn{1}{|c|}{ Items } & N & Mean & St.D & Extent \\
\hline 18 & $\begin{array}{l}\text { I consider learning English important because an } \\
\text { educated person is supposed to be able to speak } \\
\text { English. }\end{array}$ & 150 & 4.78 & .600 & VG \\
\hline 19 & $\begin{array}{l}\text { English is important because people will respect me } \\
\text { more if I have knowledge of it. }\end{array}$ & 150 & 4.90 & .453 & VG \\
\hline 20 & $\begin{array}{l}\text { I consider learning English important because people I } \\
\text { respect think that I should do it. }\end{array}$ & $\begin{array}{l}\text { I am studying English to show myself that I am a good } \\
\text { student because I can speak English. }\end{array}$ & 3.66 & .541 & $\mathrm{G}$ \\
\hline 22 & $\begin{array}{l}\text { The feeling that I am a real part of this school, which } \\
\text { requires high academic endeavour, motivates me to } \\
\text { study. }\end{array}$ & 150 & 3.50 & .564 & VG \\
\hline 23 & $\begin{array}{l}\text { The feeling that I am a real part of this school, which } \\
\text { has a very good reputation, motivates me to study. }\end{array}$ & 150 & 3.52 & .791 & G \\
\hline The feeling that learning English is important part of \\
it.
\end{tabular}

The data displayed in Table 4 shows that all the 7 items of social motivation motivated non-English majored students
English is to find opportunities at work and English will serve my future studies" (S5).

The teachers interviewed in this study also raised their opinions. For instance:

"Students are motivated to learn English when they find themselves motivated within themselves, such as a positive attitude towards English, self-confidence in communicating English. Career opportunities, social relationships, acquiring knowledge etc. will motivate them. The motivation of students to learn English will be reduced when teachers give inappropriate teaching methods, do not create excitement for students, or the curriculum is ineffective, boring, etc" (T4). Or T5 said: "I think most of them are motivated to learn English because English is for their jobs and it is one of the compulsory subjects for them to graduate from university".

\section{Social motivation}

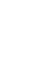

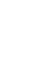


extent. They all accepted that English is important because people will respect themif they have knowledge of it, or because an educated person is supposed to be able to speak English"; and a good student must know how to speak English" with $\mathrm{M}=4.90 \& S t . \mathrm{D}=.453 ; \mathrm{M}=4.78$ \&St.D=.600; $\mathrm{M}=4.32 \&$ St. $\mathrm{D}=.571$ respectively.

Regarding the last four items of social motivation, most of the student agreed that they were true to them. That means they agreed thatstudents learn English because of many purposes. Accordingly, they often had feeling that learning English is important part of the students' life (item 24) with $\mathrm{M}=4.00 \& \mathrm{St} . \mathrm{D}=.585$. They also often considered learning English important because people they respected thought that they should do it (item 20)with $\mathrm{M}=3.66 \&$ St. $\mathrm{D}=.541$. Moreover, they were often motivated because they had feeling to be a real part of the school which had a very good reputation (item 23) and which required high academic endeavor (item 22) with $\mathrm{M}=3.52$ $\& S t . D=.791 ; M=3.50 \& S t . D=.564$ respectively.

Regarding the interviews with students and teachers, qualitative data were collected from the interview presenting similar opinions with quantitative data. For example, some students expressed their opinions:

"I am very motivated to learn English. If you talk about the level, you must say the motivation is high. Because English is very important, I can learn about human culture in countries around the world. I also have the opportunity to meet and interact with many foreigners to open my eyes. Besides, people will respect me more if I can use English well" (S1). S6 said, "I try my best to learn English well. If we talk about motivation, we have high motivation in learning English. Having good English knowledge will make me achieve what I

Some teachers also raised their opinions:

"I think most of them are motivated to learn English because English is for their jobs and it is one of the compulsory subjects for them to graduate from university." (T5)

"I find many students very motivated to learn English because they recognize the important role that English plays in their careers and their lives. However, there are also students who are not interested in learning English because they may not have an English background, so they feel bored when they focus on learning." (T1)

In conclusion, data collected from both questionnaire and interviews showed that most of the students were motivated in learning English to a great extent. They could know what they should do to join the outside world or to have a good future career with a high English proficiency level.

5.2 Factors that affect non-English majored students' motivation in learning EFL

Research question 2 attempted to explore the factors that affected students' motivation in learning EFL.

In the subsections below data collected from the questionnaire and interiews are presented and interpreted.

Student-related factors

Table 5: Descriptive Statistics of Student-related factors

\begin{tabular}{|l|l|l|l|l|}
\hline No & \multicolumn{1}{|c|}{ Items } & N & M & St.D \\
\hline 1 & My low English proficiency makes me demotivated in learning English. & 150 & 3.93 & .378 \\
\hline 2 & My lack of belief in ability demotivates my English learning. & 150 & 3.06 & .581 \\
\hline 3 & My lack of confidence demotivates my English learning. & 150 & 2.82 & .591 \\
\hline 4 & My quiet and shy personality makes me fail in learning English. & 150 & 3.02 & .737 \\
\hline
\end{tabular}

Data displayed in the Table 5show thatmost of the participants agreed and strongly agreed that student-related factors affected their motivation in learning English. Accordingly, they would be demotivated in learning English due to their low English proficiency (item 1) with $\mathrm{M}=3.93$ \&St. $\mathrm{D}=.378$, lack of belief in ability (item 2) with
$\mathrm{M}=3.06 \&$ St. $\mathrm{D}=.581$. Besides, quiet and shy personality made them fail in learning English (item 4) with $\mathrm{M}=3.02$ \&St.D=.737. At a little lower level of agreement, participants said that their lack of confidence demotivated their English learning (item 3) with $\mathrm{M}=2.82 \& \mathrm{St} . \mathrm{D}=.591$. 
Regarding data collected from the interviews with 10 students and 5 English teachers, some students expressed:

“.....Maybe due to my shyness, lack of confidence, my English skills are not good. When the teacher encourages or helps me, I am very motivated to learn English.” (S9); S5 said, “ifI am enthusiastic, actively participate in English learning activities, it will make me interested in English".

The teachers also presented their ideas on the studentsrelated factors, for example

"There are many positive and negative factors affecting students' motivation to

Table 6: Descriptive Statistics of Parents-related factors

\begin{tabular}{|c|c|c|c|c|}
\hline No & Items & $\mathbf{N}$ & $\mathbf{M}$ & St.D \\
\hline 5 & It is very motivating for me when my parents encourage me to study English & 150 & 2.75 & .432 \\
\hline 6 & I study English to avoid being punished by my parents & 150 & 2.30 & .490 \\
\hline 7 & I study English to please my parents. & 150 & 2.38 & .553 \\
\hline 8 & $\begin{array}{l}\text { My motivation increases when my parents praise me for my achievement in } \\
\text { English }\end{array}$ & 150 & 2.86 & .348 \\
\hline 9 & I study English to avoid being reprimanded by my parents. & 150 & 3.07 & .696 \\
\hline 10 & $\begin{array}{l}\text { My motivation increases when my parents show considerable interest in my } \\
\text { English studies. }\end{array}$ & 150 & 2.89 & .369 \\
\hline
\end{tabular}

The data displayed in Table 6 reveal that a majority of students thought that four parent-related factors that affected their motivation to learn English. In details, they were motivated because they wanted to avoid being reprimanded by their parents (item 9) with $\mathrm{M}=3.07 \&$ St. $\mathrm{D}=.696$. Particularly, they were motivated when their parents showed considerable interest in their English studies (item 10) with $\mathrm{M}=2.89$ \&St.D=.369, praised them for their achievement in English (item 8) with $\mathrm{M}=2.86 \& \mathrm{St} . \mathrm{D}=.348$ and encouraged them to study English (item 5) with $\mathrm{M}=2.75 \&$ St. $\mathrm{D}=.432$. However, not many studentsagreed with the factors that they studied English to avoid being punished by their parents or to please their parents (item 6, 7) with $\mathrm{M}=2.30 \& \mathrm{St} . \mathrm{D}=.490$, and $\mathrm{M}=2.38$ \&St. $\mathrm{D}=.553$ respectively.

The data collected from the interviews with students and teachersare consistent with those of the questionnaire. For example, some students reported:

"....Certainly, there are factors that make students prefer to learn English; and learn English. Like many students who have low English proficiency, they have not kept up with the English learning program so they feel frustrated and lose interest in learning English. There are students who are timid and quiet so in the English class they are not actively involved in English learning activities. In many cases when I encourage and support students, I find that they are very active in learning."

\section{Parent-related factors}

there are factors that make them feel tired and bored when having to learn English. For me, my parents have a great role to play in my English (S3)”. " ....My parents encouraged me to learn English and they were very interested in my English learning, so it made my parents happy, partly because of the future of my life; so I tried hard to learn English." (S6).

Teachers also agreed with the opinion that parent-related factors affected students' motivation in learning English. For example,

T4 expressed, "Parents have a huge role to play in promoting their children's learning. If they always encourage their children, they will learn better."

\section{Peer-related factors}


Table 7: Descriptive Statistics of Peer-related factors

\begin{tabular}{|l|l|l|l|l|}
\hline No & \multicolumn{1}{|c|}{ Items } & N & M & St.D \\
\hline 11 & It is very important for me when my friends help me with my English studies. & 150 & 2.27 & .654 \\
\hline 12 & Studying English is important in order to gain the approval of my peers & 150 & 2.10 & .506 \\
\hline 13 & It is very important for me when my friends encourage me to study English. & 150 & 2.28 & .479 \\
\hline 14 & $\begin{array}{l}\text { If I feel that my friends have a positive attitude towards learning English, it } \\
\text { motivates me to learn. }\end{array}$ & 150 & 2.39 & .784 \\
\hline 15 & $\begin{array}{l}\text { Realizing that my classmates have better marks than me motivates me to study } \\
\text { harder. }\end{array}$ & 150 & 2.80 & .590 \\
\hline 16 & $\begin{array}{l}\text { Realizing that my classmates can speak English better than me makes me make } \\
\text { my efforts. }\end{array}$ & 150 & 2.88 & .476 \\
\hline 17 & $\begin{array}{l}\text { If I feel that my classmates do not work hard on English, I lose my motivation } \\
\text { too. }\end{array}$ & 150 & 2.22 & .844 \\
\hline 18 & $\begin{array}{l}\text { Realizing that my classmates have been praised by the teacher makes me try my } \\
\text { best. }\end{array}$ & 150 & 3.04 & .693 \\
\hline 19 & $\begin{array}{l}\text { Realizing that my classmates do not show considerable progress in English and } \\
\text { still are getting good marks makes me study less hard. }\end{array}$ & 150 & 2.64 & .957 \\
\hline
\end{tabular}

In consideration of peer-related factors, the data displayed in Table 7 show that a majority of students showed their agreement on five factors affecting their motivation in learning EFL. Those factors aretheir classmates' better marks (item 15) with $\mathrm{M}=2.80$ $\&$ St. $D=.590$, their classmates speaking English better (item 16) with $\mathrm{M}=2.88 \& \mathrm{St} . \mathrm{D}=.476$, their classmates being praised by the teacher (item 18 ) with $\mathrm{M}=3.04$ and St. $\mathrm{D}=$ .693 , classmates' less progress in English (item 19) with $\mathrm{M}=2.64 \&$ St. $\mathrm{D}=.957$, and a cooperative atmosphere in the English classroom (item 20) with $\mathrm{M}=2.81 \&$ St. $\mathrm{D}=.390$.

Nevertheless, the students did not agree with five other factors. Those included items 11, 12, 13, 14 and 17. In details, many of them did not think that it was very important for them when their friends helped with English studies (item 11) with $\mathrm{M}=2.27 \& \mathrm{St} . \mathrm{D}=.654$, or studying English was important in order to gain the approval of peers (item 12) with $\mathrm{M}=2.10 \& S t . \mathrm{D}=.506$. What is more, according to them, it was not very important when their friends encouraged them to study English (item 13) with $M=2.28 \&$ St. $D=.479$. Not many of them thought that friends'positive attitudes towards learning English motivatedthem to learn English (item 14) with $M=2.39 \&$ St. $D=.784$, or that their classmates did not work hard demotivated them (item 15) with $\mathrm{M}=2.22 \&$ St. $\mathrm{D}=.844$.

In the interview, some students' responses were similar to the data collected from the questionnaire. For example, S5 stated:

“ Myclassamtes sometimes have influences on my learning. If I see that they are trying their hard to learning English, I also try although it is not easy for me. In my class some classmates usually get good marks in the English subject, which encourages me a lot." or, "...if my friends are good at English and have good grades in learning, I am very motivated to learn English". (S7).

\section{Teacher personality-related factors}


Table 8: Descriptive Statistics of Teacher personality-related factors

\begin{tabular}{|l|l|l|l|l|}
\hline No & \multicolumn{1}{|c|}{ Items } & N & M & St.D \\
\hline 21 & $\begin{array}{l}\text { I think that it is highly motivational when the English teacher promotes a } \\
\text { positive attitude towards the subject. }\end{array}$ & 150 & 3.65 & .904 \\
\hline 22 & The agreeable personality of an English teacher is very important for me & 150 & 3.12 & .481 \\
\hline 23 & If the English teacher has high expectation, it motivates me to study. & 150 & 3.04 & .605 \\
\hline 24 & $\begin{array}{l}\text { I think that it is highly motivational when the English teacher is enthusiastic for } \\
\text { their subject. }\end{array}$ & 150 & 3.82 & .714 \\
\hline 25 & The English teacher's support and care are very important for me. & 150 & 3.76 & .682 \\
\hline
\end{tabular}

The data in Table 8show that most of the students emphasized their strong agreement on three factors of teacher personality (item 24, 25, 21). They strongly agreed that it was highly motivational when the English teacher promoted a positive attitude towards the subject (item 21) with $\mathrm{M}=3.65 \& \mathrm{St} . \mathrm{D}=.904$ and when they were enthusiastic (item 24) with $\mathrm{M}=3.82 \& \mathrm{St} . \mathrm{D}=.714$. They also presented their strong agreement on the statement "The English teacher's support and care are very important for me" (item 25) with $\mathrm{M}=3.76 \& \mathrm{St} . \mathrm{D}=.682$. Regarding the last two other factors, most of the students agreed with them. They thought that

the agreeable personality of an English teacher was very important for them, and If the English teacher hadhigh expectation, it motivatedthem to study" (item 22, 23) with

$\mathrm{M}=3.12 \&$ St. $\mathrm{D}=.481 \quad$ and $\mathrm{M}=3.04 \quad$ \&St. $\mathrm{D}=.605$ respectively.

In terms of interview data, some of students emphasized the role of teacher personality in motivating students in learning English. S2 said:

\begin{abstract}
"There are factors that positively and negatively affect my English learning. Positive factors such as the teacher's positive personality, enthusiastic support, teaching methods, and correct pronunciation, English proficiency have a positive effect on my English learning."
\end{abstract}

\title{
Teacher performance-related factors
}

Table 9: Descriptive Statistics of Teacher performance-related factors

\begin{tabular}{|c|c|c|c|c|}
\hline No & Items & $\mathbf{N}$ & $\mathbf{M}$ & St.D \\
\hline 26 & $\begin{array}{l}\text { If the teacher uses varied teaching materials (pictures, videos, PPTs, clippings, } \\
\text { etc.) not only the Student's Book, it motivates me to learn. }\end{array}$ & 150 & 3.97 & .161 \\
\hline 27 & $\begin{array}{l}\text { If the learning method, the teacher chooses, is interesting, it motivates me to } \\
\text { learn. }\end{array}$ & 150 & 2.91 & .590 \\
\hline 28 & If the organization of the English classes is varied, it motivates me to learn. & 150 & 2.95 & .453 \\
\hline 29 & It is demotivating for me if the teacher's pronunciation is poor. & 150 & 2.86 & .500 \\
\hline 30 & $\begin{array}{l}\text { When a task is presented, it is important for me to understand the English } \\
\text { teacher's clear intention. }\end{array}$ & 150 & 2.90 & .583 \\
\hline 31 & It is motivating for me if the teacher has a good command of English. & 150 & 3.98 & .140 \\
\hline
\end{tabular}

The data displayed in Table 9 describe six factors relating to teacher performance in motivating students in learning English. Based on the mean scores, it can be said that most of the students strongly agreed with such factors as the teacher's good command of English (item 31) and varied teaching materials (pictures, videos, PPTs, clippings, etc.)(item 28) withM=3.98 \&St.D=.140and $\mathrm{M}=3.97$
$\&$ St.D=.161 respectively.Regarding items27, 28, 29, 30, most of the students agreed with these factors. For example, interesting teaching methods (Item 27) with $\mathrm{M}=2.91 \& \mathrm{St} . \mathrm{D}=.590$, various organizations of the English classes (item 28) with $\mathrm{M}=2.95 \& \mathrm{St} . \mathrm{D}=.453$, teacher's poor pronunciation (item 29) with $\mathrm{M}=2.86$ \&St. $\mathrm{D}=.500$, 
and teacher's clear intention when a task was presented (item 30) with $\mathrm{M}=2.90 \&$ St. $\mathrm{D}=.583$.
Obviously, these findings of the study showed that teacher's performance plays an important role in motivating students' English learning.

Teacher feedback-related factors

Table 10: Descriptive Statistics of Teacher feedback-related factors

\begin{tabular}{|l|l|l|l|l|}
\hline No & \multicolumn{1}{|c|}{ Items } & N & M & St.D \\
\hline 32 & If I obtain bad grades, I feel that I need to study harder. & 150 & 3.10 & .301 \\
\hline 33 & $\begin{array}{l}\text { If I am reprimanded for poor achievement by my teacher, I feel motivated to } \\
\text { study harder. }\end{array}$ & 150 & 2.73 & .738 \\
\hline 34 & When my teacher praises me for my performance, my motivation increases. & 150 & 2.83 & .408 \\
\hline 35 & If I am well explained what needs to be improved I feel motivated to learn it. & 150 & 3.86 & .282 \\
\hline 36 & My motivation increases when I obtain good grades. & 150 & 3.06 & .238 \\
\hline
\end{tabular}

It can be seen in Table 10that most of the students agreed that five factors related to teacher feedback affecting their motivation in learning English( $M=2.73-3.86)$. Accordingly, they thought that they needed to study harder if they obtained bad grades (item 32) with $\mathrm{M}=3.10$ $\& S t . D=.301$, or if they were reprimanded for poor achievement by their teacher (item 33) with $\mathrm{M}=2.73 \&$ St. $\mathrm{D}=.738$, or when their teacher praised them for their performance, their motivation increased (item 34) with $\mathrm{M}=2.83 \& \mathrm{St} . \mathrm{D}=.408$. Particularly, when the teacher explained to them what needed to be improved (item 35) with $3.08 \& S t . D=.282$; even when they obtained good grades (item 36) with $\mathrm{M}=3.06 \& \mathrm{St} . \mathrm{D}=.238$.

Regarding data collected from the interviews, it can be said that students could be motivated if the teacher's ways of giving feedback to the students were supported by them. For example, S4 said,

"I am very interested in things related to teachers such as teaching methods or ways of giving feedback. Teachers can

make me more motivated. For example, teachers encourage me to study if their feedback is provided to students regularly; or their efforts to help me. Another factor is the teacher's ways of praising or explaining mistakes to students".

The interview data from teachers also supported the data collected from the questionnaire, for example, T3 stated:

"In my opinion, the teaching methods of teachers have a great influence on students' motivation and learning outcomes. As I can see when I explain the lessons and they understand, the students feel excited and motivated during that lessons. Or if they do a good job and they are praised in front of the class."

\section{Classroom-related factors}

Table 11: Descriptive Statistics of Classroom-related factors

\begin{tabular}{|l|l|l|l|l|}
\hline No & \multicolumn{1}{|c|}{ Items } & N & M & St.D \\
\hline 37 & If the classroom is too crowded, it is hard for me to learn English. & 150 & 3.06 & .250 \\
\hline 38 & $\begin{array}{l}\text { There is not enough light; this will make me hard to look at the board or } \\
\text { read the textbook. }\end{array}$ & 150 & 3.12 & .326 \\
\hline 39 & $\begin{array}{l}\text { If the surrounding is too noisy, it is hard for me to concentrate on learning } \\
\text { English. }\end{array}$ & 150 & 2.71 & .583 \\
\hline
\end{tabular}

Table 11 describesthe data related toclassroom-related factors affecting students' motivation in learning English. Most of the students agreed with the three factors with $\mathrm{M}$ = from 2.71 to 3.06. Most of them thought that if the classroom were too crowded, it would be hard for them to ISSN: 2456-7620 learn English (item 37) with $\mathrm{M}=3.06$ \&St. $\mathrm{D}=.250$; andif there were not enough light; this would make them hard to look at the board or read the textbook (item 38) with $M=3.12$ \&St.D=.326. They also agreed thatif the surrounding were too noisy, it would be hard for them to 
concentrate on learning English (item 39) with $\mathrm{M}=2.71$ $\& S t . D=.583$. It is clear that classroom-related factor such as crowded classroom, not enough light, and noisy surrounding affected students' motivation to learn English.

Some students participating in the interview also emphasized the great significance of classroom-related

factors in motivating students to learn English. They stated that negative factors such as crowded classrooms, classrooms with no light, noisy classes made me unable to focus on learning English (S2).

\section{Textbook-related factors}

Table 12: Descriptive Statistics of Textbook-related factors

\begin{tabular}{|l|l|l|l|l|}
\hline No & \multicolumn{1}{|c|}{ Items } & N & M & St.D \\
\hline 40 & Lengthy and difficult tasks and texts make me bored with my leaning. & 150 & 3.00 & .827 \\
\hline 41 & $\begin{array}{l}\text { Tasks and activities in the textbook have less emphasis on speaking activities, } \\
\text { but mainly on grammar and structure, making me bored with my learning. }\end{array}$ & 150 & 3.21 & .411 \\
\hline
\end{tabular}

Apart from the above factors, textbook-related factors also affected students' motivation to learn English. As seen in Table 12, a large number of students agreed that lengthy and difficult tasks and texts made them bored with their learning (item 40) with $\mathrm{M}=3.00 \&$ St. $\mathrm{D}=.827 .0 r$, tasks and activities in the textbook had less emphasis on speaking activities, but mainly on grammar and structure, making them bored with their learning (item 41) with $\mathrm{M}=3.21$ $\&$ St.D $=.411$.

Students participating in the interviewalso stated their similar ideas with the data collected fromthe questionnaire. S1 stated:

"There are many factors that positively
and negatively affect English learning
motivation. To me, factors related to
textbooks and factors related to teachers
have a great impact on my motivation to
learn English. I really like teachers who
use ICT to teach English. The images,
audio and video make me more
motivated to learn English. When I see
teachers with good English skills,
interesting learning methods, good
pronunciation and good standards, I tend
to study English very positively.
However, when textbook materials are
boring like focusing only on grammar
and structure, it makes me bored with
my study".

In conclusion, data collected from both the questionnaire and interviews revealed that most of the students participating in this study agreed or strongly agreed that factors that affected their motivation in learning English were related to the students themselves, the teachers' teaching methods, personality or sttitudes, ways of giving feedback, classroom, and textbooks.

\subsection{Discussion}

\subsubsection{The extent to which students are motivated in learning English}

The results of the study show that three kinds of motivations, including integrative motivation, instrumental motivation, and social motivation motivated the students in learning Englishto a great extent. The result is in agreement with previous studies by Nawaz, Amin, and Tatla (2015),Kareema (2016), Qashoa (2016), Ditual (2012), Moiinvaziri (2009), MacIntyre (1999), and AlTa'ani (2018) who have found that the participants are greatly motivated by integrative, instrumental, and social motivations in learning English.

Regarding integrative motivation, the students reported that they are greatly motivated to learn English because English is very important. Having a good knowledge of English will help them to know about the culture and social life of people in English speaking countries. The students can find opportunities to live in English speaking countries and make familiar with many people over the world. Additionally, the students reported that they have great motivation to learn English because they can join in international activities. It is very ashamed if they cannot speak English in foreign context.

In consideration of instrumental motivation, most of the students agreed that instrumental motivation greatly motivates them in learning English. There is only one statement of instrumental motivation motivating the students' English learning toa moderate extent. Hong and Ganaphathy (2017) states that instrumental motivation is found to have great impact on students' English language learning. Instrumentally motivated students want to learn English language for such practical reasons as for future studies or for a good and well- paid job. The participants also said that social motivation has great impact on their English learning. In other words, they are motivated by 
social motivationto a great extent. Students want to learn English as they think that an educated person is supposed to be able to speak English and other people will respect for them if they have knowledge of English. Besides, social motivation to learn English is to show off them. They surely become good students when they can speak English.

\subsubsection{Factors affectingnon-English majored students' motivation in learning English}

It is important for researchers to find out factors affecting non-English majored students' motivation in learning English. The results of the study show that most of students agreed with 8 groups of factors influecncing their motivation, including student-related factors, parentrelated factors, peer-related factors, teacher personalityrelated factors, teacher performance-related factors, teacher feedback-related factors, cassroom-related factors, and textbook-related factors. These results are consistent withthose of previous studies conducted byRahman, Rajab,Wahab, Nor,Zakaria and Badli (2017), Ekiz and Kulmetov (2016), Sant (2018) or Kikuchi and Sakai (2009) who expressed in their studies that teachers' influence, teaching methodology, texts, tasks and tests; personal attitudes; and parental influence do have influence on students' motivation to learn a second language.

Regarding student-related factors, the finding showed that a majority of participants agreed with factors relating to students in motivating them to learn English such as low English proficiency, lack of belief in ability, lack of confidence, and quiet and shy personality. This result is in line with the result of Rahman; Rajab; Wahab; Nor; Zakaria; and Badli (2017) that show that these factors are common attibutes to motivation of demotivation. Students' successes and failures depend much on motivation. Their beliefs can either motivate academic efforts or undermine them, both in short term and in long term (Dörnyei, 2001).

In terms of parent-related factors, the results of the study show that parent-related factors had influence on students' motivation. These results show that students learn English because their parents encourage them to learn English; praise them for their achievement in English, and show their considerable interest in their English studies. Parents are considered to be a motive; families and schools are closely related in promoting learners' motivation to learn (Dornyei, 2001). What is more, classmates also play an important role in motivating their friends to learn. Their friends' better or worse marks, good or bad attitudes and so on; all may contribute to students' motivation or demotivation in learning English.

Regarding teacher-related factors such as performance, teaching methods, ways of giving feedback or personality, all have been proved to have influence on students' motivation. Many students have high motivation to learn English when their teachers have positive attitude towards the subject, and are enthusiastic for the subject. The students are also highly motivated if their teachers have high expectation, and have support and care for students' English learning. This proves that teacher personality is extremely important to students' motivation. Accordingly, teacher personality can create an optimistic view towards English subject; Referring to teacher performance, students agreed that such factors positively affect their motivation in learning English as the use of various teaching materials, the teacher's choice of learning method, the organization of English classes, teacher's pronunciation, teacher's clear intention, and teacher's good command of English. These factors are supposed to motivate students' learning at a high level. In the case that teachers give motivational feedback, students are also highly motivated. Teacher's rebuke for students' poor achievement, praise for students' performance and good grades, and teachers' explanation about what needs to be improved are motivations to promote students to try in English learning. These findings are in alignment with the theory stated by Murray et al. (2011); Hadfield \&Dörnyei (2013) and Dörnyei (2001).

The result of this research revealed that participants really considered the role of classroom in motivating their English learning. Students cannot focus on learning if the classroom is crowded, not enough light and noisy. Recognizing this, both teachers and students need to arrange classrooms with good condition so that they can obtain good results in learning and teaching. Alanguage learning classroom needs to establish relationships between the teacher and learners (Murray et al., 2011; Lasagabaster et al., 2014). The impact of these relationships in a language learning classroom confirms the importance of understanding the nature of motivation in L2 learning (Lasagabaster et al., 2014).

Finally, the final factor affecting students' motivation is the textbook. The students agreed that lengthy and difficult tasks and texts make them bored with their learning. Moreover, students will be demotivated if tasks and activities in the textbook have less emphasis on speaking activities, but mainly on grammar and structures. The chosen text should be within the learners' background knowledge and cognitive maturity because the text contains too complicated structures that are beyond 
students' comprehension and might negativelyaffect their learning.

\section{CONCLUSION AND RECOMMENDATIONS}

The present study aims to study factors affecting nonEnglish majored students' motivation at DLU. Data collected from two instruments: questionnaire and interview showed findings that the respondents maintained a high level of motivation in learning English via three kinds of motivation, including integrative motivation, instrumental motivation, and social motivation.

The findings of the study also indicated 8 groups of factors affecting students'motivation in learning English. Those are student-related factors, parents- related factors, peers-related factors, teacher personality-related factors, teacher performance -related factors, teacher feedback related factors, classroom-related factors, and textbookrelated factors. Most of students agreed that those factors affected their motivation in learning English. The findings were confirmed with more certainty when interview data are consistent with questionnaire data.

Based on the findings of the study, it can be recommended that EFL teachers should be aware of kinds of motivationand factors affecting students' motivation in learning EFL. They should find out students' needs and wants. By doing so, they can help their students to overcome difficulties through the use of motivational strategiesin their instruction. Clearly understanding the importance of motivation and factors affecting motivation is necessary for any student who wants to get success in learning English, so it is suggested that each EFL student should always take initiative, identify needs, and be dynamic and motivated in learning.

\section{REFERENCES}

[1] Al-Ta'ani, H. (2018). Integrative and instrumental motivations for learning English as a University Requirement among undergraduate students at Al-Jazeera University. International Journal of Learning and Development, 8 (4).

[2] Ayako, H. (2004). Student demotivation in the foreign language classroom.Takushoku Language Studies, 107, 119-136.

[3] Ditual, R. C. (2012).The Motivation for and attitude towards learning English.Asian EFL Journal, 63.

[4] Dornyei, Z. (2001). Motivational strategies in the language classroom. Cambridge: Cambridge University Press.

[5] Dornyei, Z. \& Murphy, T. (2003).Group dynamics in the language classroom. Cambridge: Cambridge University Press.
[6] Ekiz,S. \&Kulmetov, J. (2016). The factors affecting learners' motivation in English language education.Journal of Foreign Education and Technology, 1(1).

[7] Falout, J. \&Falout, M. (2005).The other side of motivation: Learner demotivation.JALT2004 conference proceedings (280-289). Tokyo.

[8] Falout, J. \& Maruyama, M. (2004).A comparative study of proficiency and learner demotivation.The Language Teacher, 28(8), 3-9.

[9] Gao Y. H., Zhao Y., Cheng Y., \& Zhou Y. (2004). Motivation types of Chinese university undergraduates. Asian Journal of English Language Teaching, 14, 45-64.

[10] Gardner, R. C. \& Lambert, W. E. (1972).Attitudes and motivation in second language learning. Rowley, MA: Newbury House Publishers.

[11] Gardner, S. \& Brunet, G. R. (1977). Intensive second language study: effects on attitudes, motivation and french achievement. Language Learning, 27, 243-261.

[12] Hadfield, J. \&Dörnyei, Z. (2013).Motivation learning. London: Pearson Education

[13] Hong, Y., C. \&Ganaphathy, M. (2017). To investigate ESL students' instrumental and integrative motivation towards English language learning in a Chinese School in Penang: Case study. English language teaching, 10 (9).

[14] Karrema, M. (2016).Motivation for learning English among the students of South Eastern University of Srilanka.English language unit, South Eastern University of Sri Lanka, Sri Lanka.

[15] Kikuchi, K. \& Sakai, H. (2009).Japanese learners' demotivation to study English: A survey study.JALT Journal, 31(2), 183-204.

[16] Kormos, J., \&Dörnyei, Z. (2004).The interaction of linguistic and motivational variables in second language task

performance.ZeitschriftfürInterkulturellenFremdsprachenu nterricht, 9(2), 31-37.

[17] Lasagabaster, D., Doiz, A., \& Sierra, J. M. (Eds.). (2014). Motivation and foreign language learning: From theory to practice. Revista Espanola de Linguistica Aplicada, 28(2),641-646.

[18] MacIntyre, P. D. (1999). Language Anxiety: A Review of the Research for Language Teachers. In Young, D. J. (ed.). Affect in Foreign Language and Second Language Learning (pp. 24-45). Boston, MA: McGraw-Hill.

[19] Moiinvaziri, M. (2009).Motivational orientation in English language learning: A study of Iranian undergraduate students. Available at: thttp://www.usingenglish.com/articles/moal-orientation-inenglish-learning.html

[20] Murray, G., Gao, X. \& Lamb, T. (2011). Identity, motivation, and autonomy in language learning.Toronto: Multilingual Matters.

[21] Nawaz,H., Amin, M. \&Tatla, I. (2015). Factors affecting students' motivation level to learn English as a second language in the Pakistani university context. Journal of Research and Reflections in Education, 9 (2), 103 -115 
[22] Nguyen, Kim Phuoc\& Nguyen, Tran Ai Duy (2018). Factors affecting English learning motivation of the economics students at Ho Chi Minh City Open University. Journal of Science Ho Chi Minh City Open University, $8(4), 48-62$

[23] Phan, Hung Thinh\& Nguyen, ThiQuynh Lien (2017).Factors influencing the learning attitudes of students of Da Lat University.Journal of Science and Technology Development, 14(2), 2011.

[24] Qashoa, S. (2006). Motivation among learners of English in the secondary schools in the Eastern Coast of the UAE.(Master's Thesis).Institute of Education of the British University in Dubai.

[25] Rahman, H. Rajab,A. Wahab, S. Nor,F. Zakaria,W. \&Badli, M. (2017). Factors affecting motivation in language learning.International journal of Information and Education Technology, 7 (7)

[26] Sant, N. (2018). A study on factors affecting students' motivation in the English language classroom at Maija Yang Institute of Education, Kachin State, Myanmar.Language in India, 18 (4) 